\title{
Cellulosic ethanol production by consortia of Scheffersomyces stipitis and engineered Zymomonas mobilis
}

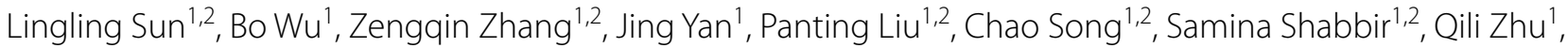
Shihui Yang ${ }^{3}$, Nan Peng ${ }^{4}$, Mingxiong $\mathrm{He}^{1,5^{*}}$ and Furong Tan ${ }^{1 *}$ (D)

\begin{abstract}
Background: As one of the clean and sustainable energies, lignocellulosic ethanol has achieved much attention around the world. The production of lignocellulosic ethanol does not compete with people for food, while the consumption of ethanol could contribute to the carbon dioxide emission reduction. However, the simultaneous transformation of glucose and xylose to ethanol is one of the key technologies for attaining cost-efficient lignocellulosic ethanol production at an industrial scale. Genetic modification of strains and constructing consortia were two approaches to resolve this issue. Compared with strain improvement, the synergistic interaction of consortia in metabolic pathways should be more useful than using each one separately.
\end{abstract}

Results: In this study, the consortia consisting of suspended Scheffersomyces stipitis CICC1960 and Zymomonas mobilis 8b were cultivated to successfully depress carbon catabolite repression (CCR) in artificially simulated 80G40XRM. With this strategy, a 5.52\% more xylose consumption and a 6.52\% higher ethanol titer were achieved by the consortium, in which the inoculation ratio between $S$. stipitis and Z. mobilis was 1:3, compared with the Z. mobilis 8b monofermentation. Subsequently, one copy of the xylose metabolic genes was inserted into the $Z$. mobilis $8 \mathrm{~b}$ genome to construct Z. mobilis FR2, leading to the xylose final-consumption amount and ethanol titer improvement by $15.36 \%$ and $6.81 \%$, respectively. Finally, various corn stover hydrolysates with different sugar concentrations (glucose and xylose $60,90,120 \mathrm{~g} / \mathrm{L}$ ), were used to evaluate the fermentation performance of the consortium consisting of S. stipitis CICC1960 and Z. mobilis FR2. Fermentation results showed that a 1.56-4.59\% higher ethanol titer was achieved by the consortium compared with the Z. mobilis FR2 mono-fermentation, and a 46.12-102.14\% higher ethanol titer was observed in the consortium fermentation when compared with the S. stipitis CICC1960 mono-fermentation. Furthermore, qRT-PCR analysis of xylose/glucose transporter and other genes responsible for CCR explained the reason why the initial ratio inoculation of 1:3 in artificially simulated 80G40XRM had the best fermentation performance in the consortium.

Conclusions: The fermentation strategy used in this study, i.e., using a genetically modified consortium, had a superior performance in ethanol production, as compared with the S. stipitis CICC1960 mono-fermentation and the Z. mobilis FR2 mono-fermentation alone. This result showed that this strategy has potential for future lignocellulosic ethanol production.

\footnotetext{
*Correspondence: hemingxiong@caas.cn; tanfurong@caas.cn

${ }^{1}$ Key Laboratory of Development and Application of Rural Renewable

Energy, Ministry of Agriculture and Rural Affairs, Biogas Institute

of Ministry of Agriculture and Rural Affairs, Chengdu 610041, China

Full list of author information is available at the end of the article
} permits use, sharing, adaptation, distribution and reproduction in any medium or format, as long as you give appropriate credit to the original author(s) and the source, provide a link to the Creative Commons licence, and indicate if changes were made. The images or other third party material in this article are included in the article's Creative Commons licence, unless indicated otherwise in a credit line to the material. If material is not included in the article's Creative Commons licence and your intended use is not permitted by statutory regulation or exceeds the permitted use, you will need to obtain permission directly from the copyright holder. To view a copy of this licence, visit http://creativecommons.org/licenses/by/4.0/. The Creative Commons Public Domain Dedication waiver (http://creativeco mmons.org/publicdomain/zero/1.0/) applies to the data made available in this article, unless otherwise stated in a credit line to the data. 
Keywords: S. stipitis, Z. mobilis, Carbon catabolite repression, Ethanol fermentation, Corn stover hydrolysate

\section{Background}

Lignocellulosic biomass is produced by plant photosynthesis from solar energy and is the most abundant renewable feedstock in the world. The bio-conversion of lignocellulosic biomass into ethanol is viewed as one of the most promising ways to partially replace traditional fossil fuels, since the combustion of ethanol produces less particulate matter, carbon monoxide, and hydrocarbons than fossil fuels [1]. In addition, as bioethanol has a high octane number, mixing bioethanol with gasoline could improve the anti-detonating quality of transportation fuel.

Lignocellulosic biomass is primarily degraded into glucose and xylose after pretreatment and enzymatic hydrolysis. The simultaneous and efficient bioconversions of the two sugars into ethanol are the prerequisites for large-scale production of cellulosic ethanol. However, due to carbon catabolite repression (CCR), a considerable amount of wild microbes and engineered microbes having exogenous xylose-metabolic pathways, such as Zymomonas mobilis, Escherichia coli, Saccharomyces cerevisiae and Bacillus amyloliquefaciens, prefer to use glucose, and therefore, their xylose utilization generally lags behind glucose utilization [2-5]. This greatly hampers the large-scale application of cellulosic ethanol in industry.

Extensive studies have been attempted to relax CCR. For example, as all known xylose transporters are suppressed by glucose, many researchers have tried to engineer glucose-insensitive xylose transporters by evolutionary engineering, error-prone PCR, and sitedirected mutagenesis. By this way, researchers have successfully built Gal2-N376F, CiGXS1 FIVFH497* and AN25-R4.18 [6-8]. In addition, adaptive evolution, computation simulation, and rational design have been used to find appropriate intracellular targets to alleviate CCR, such as the phosphoenolpyruvate transferase system (PTS), the cyclic AMP receptor protein (CRP), and the xylose operon regulatory protein $[9,10]$. However, the complex nature of CCR makes it difficult to entirely reveal how CCR functions. Moreover, those above engineered strains developed cannot co-utilize glucose and xylose with high efficiency [9].

An alternative method is to build artificial consortia to co-ferment glucose and xylose. A common practice is to build a consortium consisting of a xylose-specific strain due to the deficiency in the PTS system and a wild strain that utilizes glucose because of CCR [9]. In this way, $20.82 \mathrm{~g} / \mathrm{L}$ butanol with a yield of $0.35 \mathrm{~g} / \mathrm{g}$ was produced from glucose and xylose using two E. coli strains.
These results were comparable with butanol titers and yields produced in previous studies from glucose alone [11]. Another strategy is to use two wild species to ferment the glucose and xylose mixture. For example, when Scheffersomyces stipitis and S. cerevisiae were cofermented, the xylose removal efficiency and ethanol production showed remarkable improvement than in their mono-fermentation [12]. In comparison with twostage fermentation (glucose and xylose are consumed in a separate fashion), the consortium fermentation was advantageous in terms of assimilating glucose and xylose concomitantly and shortening fermentation time. Compared with strain improvement, the consortia might realize the exchange and transmission of substances, signals and energy between different cells, improve the adaptability and robustness of the population to complex environment. The synergistic interaction of their metabolic pathways also should be more useful than using each one separately. However, the challenge of consortia is selecting suitable strains which minimize the probable negative interactions.

Zymomonas mobilis is an excellent ethanol-producing species whose ethanol production efficiency can reach as high as $98 \%$, which is higher than $S$. cerevisiae [13]. However, the wild $Z$. mobilis cannot utilize xylose unless it has been transformed by the exogenous xylose metabolic pathway, such as Z. mobilis 8b [14]. In addition, S. stipitis is recognized as one of the best microbes in nature in terms of its xylose assimilation ability, but it has a severe CCR phenomenon. In recent studies, the consortium of S. stipitis and Z. mobilis has been studied for the co-fermentation of glucose and xylose. However, these studies generally involved two-stage fermentation, or the total sugar concentrations in lignocellulosic hydrolysate medium were low, which is unrealistic in largescale fermentation [15-18]. Even for simulated medium containing pure sugars, the xylose removal efficiency still requires improvement [19].

The present work focuses on investigating the potential of consortium fermentation consisting of S. stipitis and $Z$. mobilis in a simulated medium and corn stover hydrolysate, with a great emphasis on alleviating CCR, increasing the sugar removal efficiency, and increasing the bioethanol production. The corn stover was chosen since it is one of the most common annual agricultural wastes produced in China [20]. Transforming corn stover into industrial products, such as ethanol, not only realizes the resource utilization of this waste, but also contributes to the progress of global warming mitigation. 


\section{Results and discussion}

\section{Co-culture of S. stipitis CICC1960 and Z. mobilis 8b in 80G40XRM}

Artificially simulated 80G40XRM $(80 \mathrm{~g} / \mathrm{L}$ glucose $+40 \mathrm{~g} / \mathrm{L}$ xylose) was first used to explore the appropriate mode of this consortium fermentation with the aim of improving the glucose-and-xylose co-utilization efficiency. The ratio between glucose and xylose in this medium was 2:1, aiming to simulate the real ratio in lignocellulosic hydrolysates [21].

In a previous study [22], when S. stiptis was pre-cultured in the medium with glucose as the sole carbon source (glucose medium), its xylose-metabolic gene expression, such as D-xylose reductase and xylitol dehydrogenase expression, was inhibited. Hence, when S. stiptis was inoculated in the xylose medium (xylose was the sole carbon source in the fermentation medium) later, its xylose-metabolic genes needed to be synthesized from scratch. Therefore, S. stiptis exhibited an apparent lag in fermentation in the xylose medium. In contrast, when S. stiptis was precultured in the xylose medium, the two xylose-metabolic genes were fully expressed and the aforementioned problem of lag in the xylose fermentation was alleviated, especially if $S$. stiptis was inoculated with high initial density, such as $\mathrm{OD}_{620}=40$. To this end, we decided to preculture S. stiptis CICC1960 in YP120X (120 g/L xylose) and then inoculate it to the 80G40XRM (fermentation medium) with a "high density" and a "low amount" of inoculum fermentations, hoping to alleviate the CCR phenomenon in S. stiptis. However, as shown in Fig. 1 (with "high density" inoculums) and Additional file 1: Fig. S1 (with "low amount" inoculums), S. stipitis CICC1960 still could not simultaneously assimilate glucose and xylose. This might have been a result of the glucose repression on xylose transportation into the cells [6], or the inoculum size used in this study (the initial $\mathrm{OD}_{600}$ in fermentation was about 1.8) was not high enough. For economic reasons, the inoculum size was not further increased in this study.

For Z. mobilis 8b, 80G40XRM was used as its seed culture medium, since $Z$. mobilis $8 \mathrm{~b}$ cannot grow well in xylose medium (data not shown). The results of the
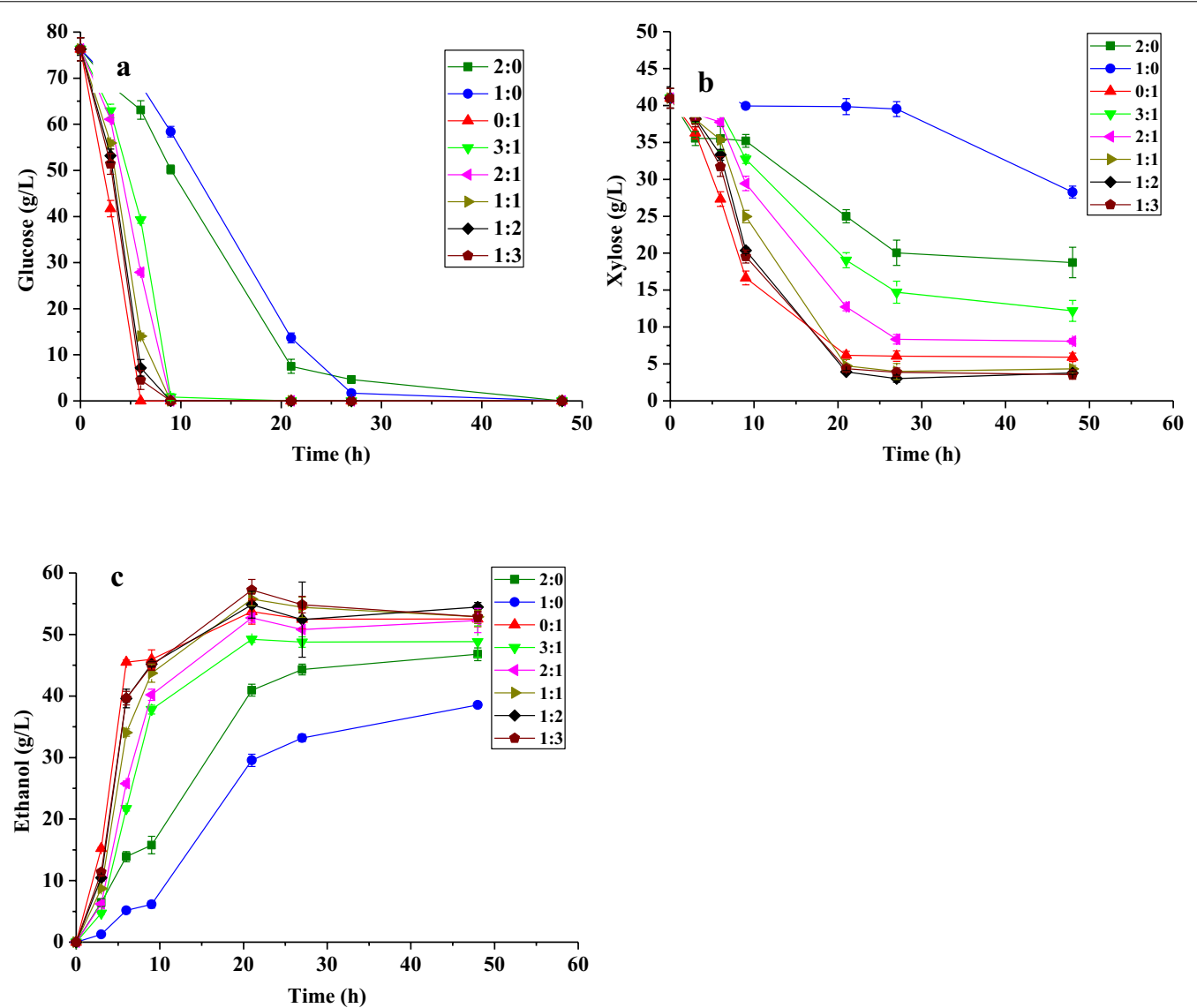

Fig. 1 Fermentation profiles of consortia consisting of S. stipitis CICC1960 and Z. mobilis 8b in 80G40XRM with "high density" inoculums of fermentations. a Glucose assimilation profiles. $\mathbf{b}$ Xylose assimilation profiles. $\mathbf{c}$ Ethanol production profiles. Data are mean \pm standard error from four replicates 
Z. mobilis $8 \mathrm{~b}$ mono-fermentation are shown in Fig. 1 and Additional file 1: Table S1 and Fig. S1. During fermentation with "high density" of inoculum, Z. mobilis $8 \mathrm{~b}$ showed a strong ability to utilize glucose and xylose simultaneously with ethanol productivity reaching $5.10 \mathrm{~g} / \mathrm{L} / \mathrm{h}$. More specially, the CCR in $Z$. mobilis $8 \mathrm{~b}$ was largely alleviated, which may be attributed to the high inoculum size used in this study (the initial $\mathrm{OD}_{600}$ was approximately 1.8). In 2004, Ali Mohagheghi et al. found that $Z$. mobilis $8 \mathrm{~b}$ (the initial inoculum density was 0.2 at $600 \mathrm{~nm}$ ) exhibited an apparent lag of xylose utilization, while glucose could be assimilated immediately [23]. Since the xylose-metabolic genes were inserted to the genome of $Z$. mobilis $8 \mathrm{~b}$, their expression was generally low in individual cells. When $Z$. mobilis $8 \mathrm{~b}$ were inoculated with high density, activities of those enzymes encoding xylose-metabolic genes would be higher than the ones under a low initial density inoculation, and this may contribute to the alleviation of CCR in this study [14]. Glucose was completely removed within $6 \mathrm{~h}$ by $Z$. mobilis $8 \mathrm{~b}$, while xylose still remained at $6.16 \mathrm{~g} / \mathrm{L}$ at $21 \mathrm{~h}$. The ethanol yield of the $Z$. mobilis $8 \mathrm{~b}$ mono-fermentation was $0.48 \mathrm{~g} / \mathrm{g}$ (the theoretical ethanol yield is $0.51 \mathrm{~g} / \mathrm{g}$ sugars).

When S. stipitis CICC1960 and Z. mobilis 8b were co-cultured together with different inoculation ratios (3:1-1:3) with "high density" of inoculum, the glucose consumption profiles of the consortia did not differ considerably from the $Z$. mobilis $8 \mathrm{~b}$ mono-fermentation (Fig. 1a). Glucose was completely removed within $9 \mathrm{~h}$ by the consortia. On top of this, no apparent CCR was shown since xylose was rapidly assimilated at the very early stage (Fig. 1b). Although xylose consumption rates by the consortia were lower than that in the $Z$. mobilis $8 \mathrm{~b}$ mono-fermentation. It was shown that, in general, the higher the ratio of $Z$. mobilis $8 \mathrm{~b}$ applied, the higher the rates of xylose assimilation achieved. Specially, when S. stipitis CICC1960:Z. mobilis $8 \mathrm{~b}=3: 1$ (initial inoculum size proportion), the xylose assimilation rate was $0.92 \mathrm{~g} / \mathrm{L} / \mathrm{h}$; when S. stipitis CICC1960: Z. mobilis $8 \mathrm{~b}=1: 3$, the xylose assimilation rate improved to $2.38 \mathrm{~g} / \mathrm{L} / \mathrm{h}$. At $21 \mathrm{~h}$, the consortia fermentation reached the endpoint of fermentation. Interestingly, when S. stipitis CICC1960:Z. mobilis $8 \mathrm{~b}=1: 3$, the xylose consumption reached $36.73 \mathrm{~g} / \mathrm{L}$, which was significantly $(\mathrm{P}<0.01)$ higher than that in the S. stipitis CICC1960 mono-fermentation and that in the Z. mobilis 8b mono-fermentation (Additional file 1: Table S1). Correspondingly, the ethanol titer of this consortium reached $57.21 \mathrm{~g} / \mathrm{L}$, which was $48.37 \%$ higher than that of the S. stipitis CICC1960 mono-fermentation and $6.52 \%$ higher than that of the Z. mobilis $8 \mathrm{~b}$ mono-fermentation. These results (S. stipitis CICC1960:Z. mobilis $8 \mathrm{~b}=1: 3$ ) were comparable with or better than other consortia fermentations listed in Table 1, in terms of xylose removal efficiency, ethanol yield, and ethanol productivity. To explain the best results observed were not due to the inoculum size of $Z$. mobilis, but to the presence of $S$. stipitis, the results of "S. stipites: $Z$. mobilis $=2: 0$ " were compared with "S. stipitis: Z. mobilis=1:1". The results (Fig. 1) showed that the xylose utilization and ethanol yield of higher initial inoculation amount of $S$. stipitis (2:0) were better than that of 1:0 inoculation amount; however, it was still not better than that of the consortium (S. stipitis: $Z$. mobilis $=1: 1$ ) and other consortia.

Table 1 Comparison of various consortia fermentation profiles in simulated medium

\begin{tabular}{|c|c|c|c|c|c|}
\hline Fermentation mode ${ }^{a}$ & Initial sugar concentration (g/L) & $\begin{array}{l}\text { Xylose removal } \\
\text { efficiency (\%) }\end{array}$ & $\begin{array}{l}\text { Ethanol } \\
\text { yield }(g / g)\end{array}$ & $\begin{array}{l}\text { Ethanol } \\
\text { productivity } \\
\text { (g/L/h) }\end{array}$ & References \\
\hline \multicolumn{6}{|l|}{ Two-stage fermentation } \\
\hline Suspended Z. mobilis + suspended S. stipitis & $80 \mathrm{~g} / \mathrm{L}$ glucose $+40 \mathrm{~g} / \mathrm{L}$ xylose & 62.5 & - & 1.56 & {$[15]$} \\
\hline Suspended S. stipitis + suspended Z. mobilis ${ }^{\mathrm{b}}$ & $60 \mathrm{~g} / \mathrm{L}$ xylose $+100 \mathrm{~g} / \mathrm{L}$ glucose & - & 0.474 & 1.416 & {$[16]$} \\
\hline Suspended Z. mobilis + suspended S. stipitis & $80 \mathrm{~g} / \mathrm{L}$ glucose $+40 \mathrm{~g} / \mathrm{L}$ xylose & 0.67 & 0.36 & 0.41 & {$[19]$} \\
\hline \multicolumn{6}{|l|}{ One-stage fermentation } \\
\hline Suspended S. cerevisiae + suspended S. stipitis & $75 \mathrm{~g} / \mathrm{L}$ glucose $+30 \mathrm{~g} / \mathrm{L}$ xylose & 79.6 & 0.4 & 1.26 & {$[41]$} \\
\hline Suspended S. cerevisiae + suspended S. stipitis & $20 \mathrm{~g} / \mathrm{L}$ glucose $+10 \mathrm{~g} / \mathrm{L}$ xylose & - & 0.416 & 0.608 & {$[42]$} \\
\hline Immobilized Z. mobilis + immobilized S. stipitis ${ }^{c}$ & $80 \mathrm{~g} / \mathrm{L}$ glucose $+40 \mathrm{~g} / \mathrm{L}$ xylose & 72.5 & 0.37 & 0.87 & {$[19]$} \\
\hline Suspended Z. mobilis + suspended S. stipitis ${ }^{d}$ & $80 \mathrm{~g} / \mathrm{L}$ glucose $+40 \mathrm{~g} / \mathrm{L}$ xylose & 84.95 & 0.50 & 4.99 & This study \\
\hline
\end{tabular}


Due to the outstanding fermentation ability of this consortium (S. stipitis CICC1960:Z. mobilis $8 \mathrm{~b}=1: 3$ ), the ratio between $S$. stipitis and $Z$. mobilis of 1:3 was later employed in the fermentation of corn stover hydrolysate.

\section{Genetic engineering of $Z$. mobilis $\mathbf{8 b}$}

In Z. mobilis, ZMO0256 encoding D-lactate dehydrogenase is involved in the production of lactate as a byproduct; ZMO0689 encoding glucose-fructose oxidoreductase participates in xylitol and sorbitol production [24]. It was demonstrated that disruption of ZMO0689 could improve xylose fermentation performance of $Z$. mobilis [25]. To introduce one copy of xylose metabolic genes (xylA, xylB, tktA, talB) into the $Z$. mobilis $8 \mathrm{~b}$ genome and improve its xylose assimilation performance, the engineered strains $Z$. mobilis FR1 (ZMO0256:: $\mathrm{P}_{p d c}$-talB-tktA) and Z. mobilis FR2
(ZMO0256:: $\mathrm{P}_{p d c}$-talB-tktA; ZMO0689:: $\left.\mathrm{P}_{p d c}-x y l A-x y l B\right)$ were sequentially constructed.

The fermentation performances of $Z$. mobilis FR1 and $Z$. mobilis FR2 were evaluated in 80G40XRM and were compared with their parental stain $Z$. mobilis $8 \mathrm{~b}$. As shown in Fig. 2a, the three strains did not differ in their glucose assimilation profiles, and glucose was depleted within $8.5 \mathrm{~h}$. For the xylose consumption and ethanol production profiles (Fig. 2b, c), Z. mobilis FR1 did not show much difference with $Z$. mobilis $8 \mathrm{~b}$. However, Z. mobilis FR2 accelerated its xylose assimilation rate in the mid-to-late fermentation period (Fig. 2b): the xylose consumption and ethanol production achieved by $Z$. mobilis FR2 were increased by $15.36 \%$ and $6.81 \%$, respectively, at $20.5 \mathrm{~h}$ as compared with $Z$. mobilis 8b (Additional file 1: Table S2). Besides, the ethanol productivity of $Z$. mobilis FR2 was $5.08 \mathrm{~g} / \mathrm{L} / \mathrm{h}$, a

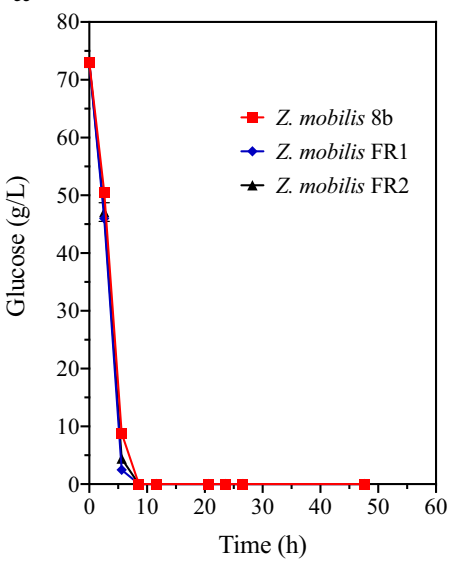

d

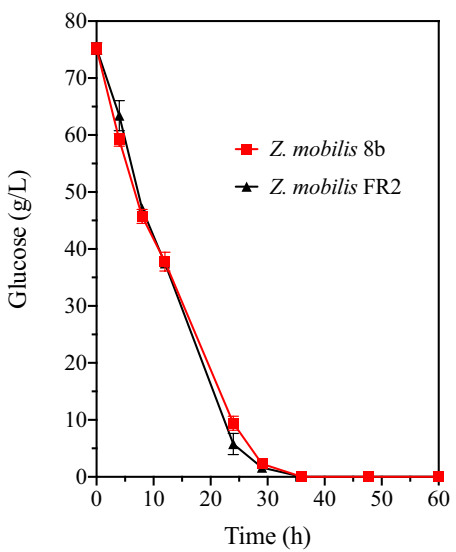

b

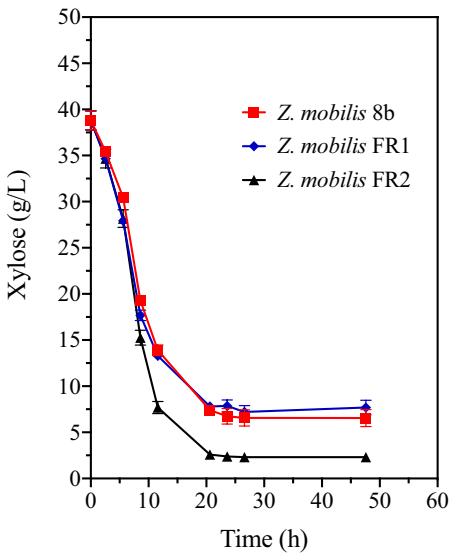

e

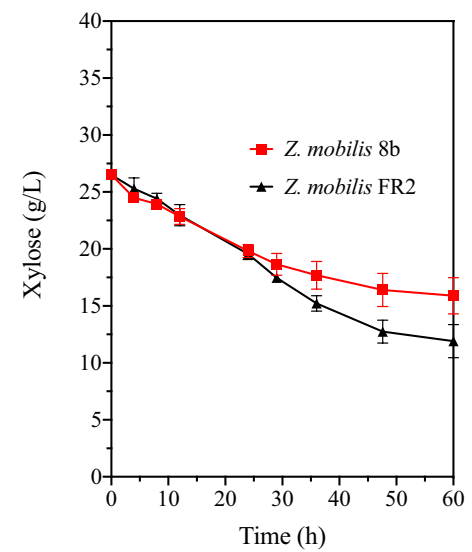

c

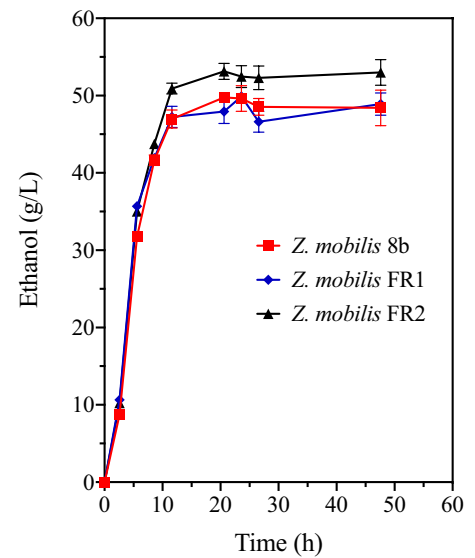

f

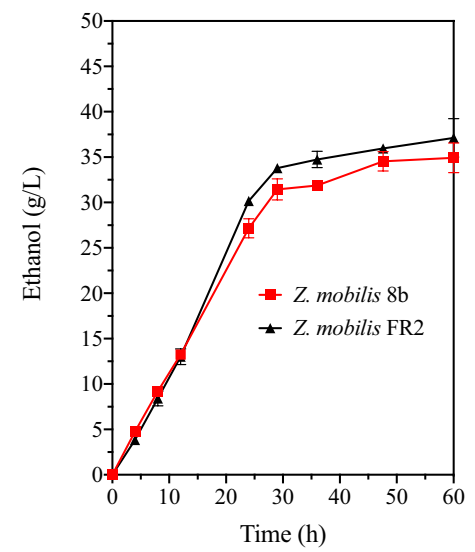

Fig. 2 Fermentation profiles of Z. mobilis 8b, Z. mobilis FR1, and Z. mobilis FR2 in 80G40XRM and in corn stover hydrolysate. a, b, c Glucose, xylose, and ethanol production, respectively, in 80G40XRM; $\mathbf{d}, \mathbf{e}, \mathbf{f}$ Glucose, xylose and ethanol production in corn stover hydrolysate. The total concentration of glucose and xylose in the hydrolysate was $120 \mathrm{~g} / \mathrm{L}$ before autoclave sterilization. Data are mean \pm standard error from four replicates 
which was significantly $(\mathrm{P}<0.01)$ higher than $Z$. mobilis $8 \mathrm{~b}(4.84 \mathrm{~g} / \mathrm{L} / \mathrm{h})$. The higher xylose-to-ethanol transforming rate in $Z$. mobilis FR2 fermentation could be attributed to the extra introduction of four xylose metabolic genes $(x y l A, x y l B, t k t A, t a l B)$. As the expression of the four genes are all controlled under the constitutive promoter $p d c$, the expression levels of their protein products (xylose isomerase, xylulokinase, transketolase, transaldolase) in Z. mobilis FR2 are higher than its parental strain $Z$. mobilis 8 b. Therefore, xylose was transformed into fructose-6-P and flyceraldehyde3-P and then entered the Entner-Doudoroff pathway in a greater speed (Additional file 1: Fig. S2), and finally contributes to the improvement of ethanol productivity in Z. mobilis FR2 fermentation. The ethanol yield of $Z$. mobilis FR2 was $95.47 \%$, which was comparable with A3 (96.6\%) and AD50 (96\%), the two best strains developed so far by adaptive laboratory evolution $[24,26]$. However, as shown in Fig. 2a, b, though CCR was alleviated in Z. mobilis FR2 fermentation, its xylose utilization rate was still lower than its glucose utilization rate, and there was still a slight amount of xylose that remained (approximately $2.5 \mathrm{~g} / \mathrm{L}$ ) at the endpoint. These results agreed with other $Z$. mobilis strains, including C25, 39,676/pZB4L [27], ZM4/Ac ${ }^{R}$ (pZB5, pJX1) [28], A3 [24], and AD50 [26], yet no exact reason of the incomplete xylose utilization has been identified thus far. In Z. mobilis, xylose is transported through a glucose facilitated diffusion protein [26], which is a native glucose transporter and has low affinity to xylose. This low affinity xylose transport might be the burden behind the above-mentioned problems. Further investigation into this field would greatly promote the commercialization of cellulosic ethanol.

\section{Effect of oxygen on Z. mobilis FR2 fermentation}

In the above experiments, as $S$. stipitis could not grow under static cultivation, $150 \mathrm{rpm}$ was applied in the $S$. stipitis mono-fermentation, the $Z$. mobilis mono-fermentation, and the consortia fermentation that consisted of the two species. However, as Z. mobilis is a facultative anaerobe, it can ferment under both static and aerobic conditions. Therefore, a further study was conducted to check whether there was any difference in Z. mobilis FR2 fermentation profiles under static and agitated (150 rpm) conditions in 80G40XRM. As shown in Fig. 3, oxygen significantly boosted $Z$. mobilis FR2's glucose $(\mathrm{P}<0.05)$ and xylose $(\mathrm{P}<0.01)$ consumption rates and improved ethanol productivity by $54.51 \%(\mathrm{P}<0.01)$. However, at fermentation endpoint $(27 \mathrm{~h}$ ), the static fermentation of $Z$. mobilis FR2 showed an increase in xylose consumption and ethanol production by $1.65 \mathrm{~g} / \mathrm{L}$ and $3.45 \mathrm{~g} / \mathrm{L}$, respectively, compared with that in agitated fermentation. To achieve high ethanol productivity, ethanol fermentation under $150 \mathrm{rpm}$ was kept in this study.

Since the theoretical ethanol yield is $0.51 \mathrm{~g} / \mathrm{g}$ xylose, the $1.65 \mathrm{~g} / \mathrm{L}$ more xylose consumed by $Z$. mobilis FR2 in static condition, in theory, should be transformed into $0.84 \mathrm{~g} / \mathrm{L}$ more ethanol. However, the real difference in ethanol titers between the static fermentation and agitated fermentation was as high as $3.45 \mathrm{~g} / \mathrm{L}$. This suggests oxygen had a negative effect on ethanol production by $Z$. mobilis FR2. In 1990, Tanaka et al. found that $Z$. mobilis produced a little more acetaldehyde $(0.28-4.49 \mathrm{~g} / \mathrm{L})$ when oxygen was supplied [29]. Acetaldehyde was primarily produced by NADH dehydrogenase, one of the key components in the $Z$. mobilis respiratory chain. This enzyme has the same cofactor (NADH) as ethanol dehydrogenase. During aerobic fermentation, the activity of $\mathrm{NADH}$ dehydrogenase was higher than that of ethanol
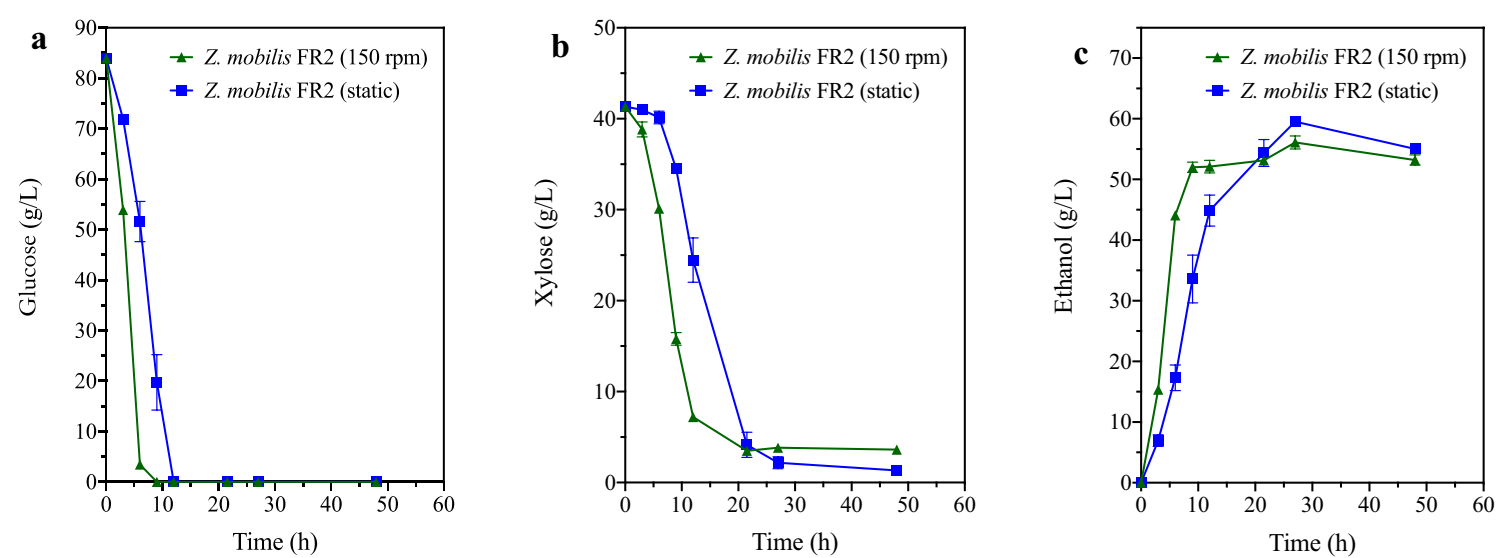

Fig. 3 Fermentation profiles of Z. mobilis FR2 in 80G40XRM with different rotation speeds. a Glucose assimilation profiles. b Xylose assimilation profiles. c Ethanol production profiles. Data are mean \pm standard error from four replicates 
dehydrogenase. Therefore, a large amount of NADH was used to reduce the dissolved oxygen concentration in the medium. Due to the lack of sufficient NADH, the transformation from acetaldehyde to ethanol by ethanol dehydrogenase was inhibited, and thus negatively affected the ethanol production of $Z$. mobilis under agitated cultivation [30]. One evidence for this hypothesis is that for $Z$. mobilis mutant strains, whose NADH dehydrogenase is defective, this negative effect of oxygen on Z. mobilis ethanol fermentation could be alleviated [31-33].

\section{Assimilation of corn stover hydrolysates by consortium composed of S. stipitis CICC1960 and Z. mobilis FR2}

First, it was evaluated whether $Z$. mobilis FR2 could outcompete $Z$. mobilis $8 \mathrm{~b}$ in corn stover hydrolysate fermentation. As shown in Fig. $2 \mathrm{~d}$ a difference was not observed regarding glucose assimilation ability of the two strains: glucose assimilation rates were $2.54 \mathrm{~g} / \mathrm{L} / \mathrm{h}$ and $2.51 \mathrm{~g} / \mathrm{L} / \mathrm{h}$ for Z. mobilis FR2 and Z. mobilis 8b, respectively, and glucose was depleted within $30 \mathrm{~h}$. As for xylose assimilation (Fig. 2e), though the two strains did not exhibit a difference during the first $24 \mathrm{~h}$, the assimilation rate of $Z$. mobilis $8 \mathrm{~b}$ gradually decreased, while the rate for $Z$. mobilis FR2 remained stable. At 60 h, Z. mobilis FR2 assimilated $14.60 \mathrm{~g} / \mathrm{L}$ xylose, which was significantly higher $(\mathrm{P}<0.05)$ than that of $Z$. mobilis $8 \mathrm{~b}(10.60 \mathrm{~g} / \mathrm{L})$. In addition, $Z$. mobilis $\mathrm{FR} 2$ produced $37.13 \mathrm{~g} / \mathrm{L}$ ethanol in $120 \mathrm{~g} / \mathrm{L}$ corn stover hydrolysate (concentration here refers to the total amount of glucose and xylose in corn stover hydrolysate before sterilization), while $Z$. mobilis $8 \mathrm{~b}$ produced $34.93 \mathrm{~g} / \mathrm{L}$ ethanol (Fig. 2f). These results agreed with the fermentation results in 80G40XRM (Fig. 2a, b, c). Due to the better xylose assimilation ability of $Z$. mobilis FR2, Z. mobilis FR2 was used to replace $Z$. mobilis $8 \mathrm{~b}$ in the next consortium fermentation with $S$. stipitis CICC1960 in corn stover hydrolysates.

As shown in Fig. 4, while consortium fermentation (S. stipitis CICC1960:Z. mobilis FR2=1:3) and Z. mobilis FR2 mono-fermentation did not show any difference in glucose and xylose consumption rates and amounts in the 60 and $90 \mathrm{~g} / \mathrm{L}$ corn stover hydrolysates fermentation, the consortium produced slightly more ethanol $(\sim 0.86 \mathrm{~g} / \mathrm{L})$ than the $Z$. mobilis FR2 mono-fermentation (Table 2). In addition, the consortium fermentation in the two cases was better than the S. stipitis CICC1960 monofermentation in terms of glucose assimilation, xylose assimilation, and ethanol production rates and quantities, and did not exhibit strong CCR which was evident in the S. stipitis CICC1960 mono-fermentation (Fig. 4). For the $120 \mathrm{~g} / \mathrm{L}$ corn stover hydrolysate fermentation, the glucose assimilation rate of the consortium $(2.83 \mathrm{~g} / \mathrm{L} / \mathrm{h})$ was slightly slower than $Z$. mobilis FR2 $(3.24 \mathrm{~g} / \mathrm{L} / \mathrm{h})$, while xylose assimilation rates were nearly the same prior to $36 \mathrm{~h}$. However, the consortium finally produced $33.05 \mathrm{~g} / \mathrm{L}$ ethanol at endpoint, which was $1.02 \mathrm{~g} / \mathrm{L}$ higher than the Z. mobilis FR2 mono-fermentation and $16.7 \mathrm{~g} / \mathrm{L}$ higher than the S. stipitis CICC1960 mono-fermentation (Table 2).

In 2014, Lalit K. Singh et al. separated kans grass hydrolysate into a xylose-rich portion and a glucose-rich portion through organic solvent extraction and then used S. stipitis and Z. mobilis to ferment each sugar $(54 \mathrm{~g} / \mathrm{L}$ xylose and $100 \mathrm{~g} / \mathrm{L}$ glucose) sequentially. The ethanol productivity in their study was $0.723 \mathrm{~g} / \mathrm{L} / \mathrm{h}$, which was lower than that in our study $(1.11-2.18 \mathrm{~g} / \mathrm{L} / \mathrm{h})$ [16]. This was because the two-stage fermentation Lalit K. Singh et al. employed led to an increase in the fermentation time. In 2020, Ferdian Wirawan et al. used immobilized Z. mobilis and S. stipitis to sequentially ferment $50 \mathrm{~g} / \mathrm{L}$ sugarcane bagasse [17]. Though the productivity in their study was high $(1.868 \mathrm{~g} / \mathrm{L} / \mathrm{h})$, the actual sugar concentration in the hydrolysate was only $11 \mathrm{~g} / \mathrm{L}$ glucose, $4 \mathrm{~g} / \mathrm{L}$ xylose, and $4 \mathrm{~g} / \mathrm{L}$ cellobiose, which is impractical in real applications. These comparisons demonstrated that the consortium fermentation mode utilized in this study has an edge in ethanol production compared with other existed modes of S. stipitis and Z. mobilis co-fermentation.

We note that the ethanol titer and productivity values in the $120 \mathrm{~g} / \mathrm{L}$ corn stover hydrolysate were lower than the values in 80G40XRM (Table 2, Additional file 1: Tables S1 and S2). This was because many of the inhibitors, such as phenols, were presented in the corn stover hydrolysate [34]. These inhibitors negatively affected the microbial fitness in the lignocellulosic hydrolysate and thus reduced the ethanol yield and productivity. Although it has been shown that the immobilization of microbes could alleviate the negative effect to some degree, the exact mechanisms are not clear [35].

Duong Thi Thuy Nguyen et al. found that the presence of living $Z$. mobilis cells negatively affected the xylose assimilation performance of $S$. stipitis, suggesting that there might be an amensalism relationship between the two species $[19,36]$. Similarly, in our study, when the initial inoculum $\mathrm{OD}_{600}$ was controlled to 0.1 in the 80G40XRM fermentation, no improvement was observed in the consortium fermentation profiles compared with the Z. mobilis mono-fermentation profiles (data not shown). In contrast, when a high inoculum size (an initial $\mathrm{OD}_{600}$ of approximately 1.8) was used, the consortium of S. stipitis and Z. mobilis assimilated more xylose and produced more ethanol in both the 80G40XRM and $120 \mathrm{~g} / \mathrm{L}$ corn stover hydrolysate. This implied a commensalism or cooperation relationship between the two species during fermentation [36]. Perhaps this positive relationship could only be exhibited under specific conditions, such as under a high cell density. 

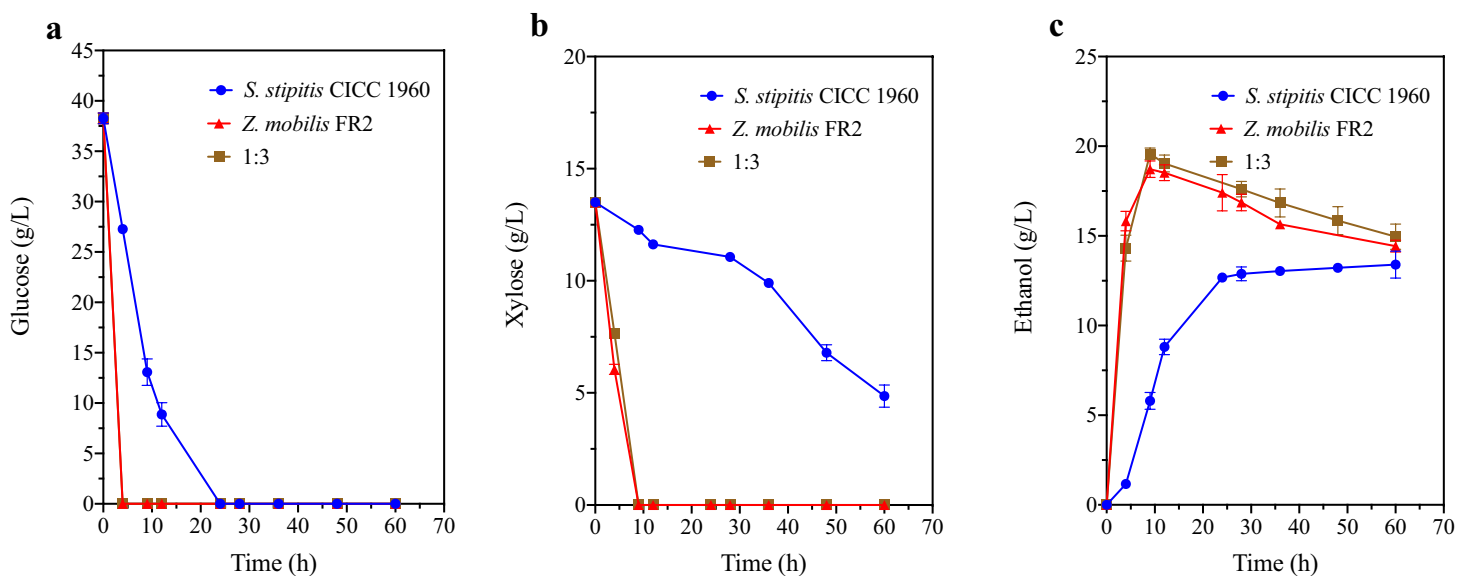

d

$$
\text { e }
$$
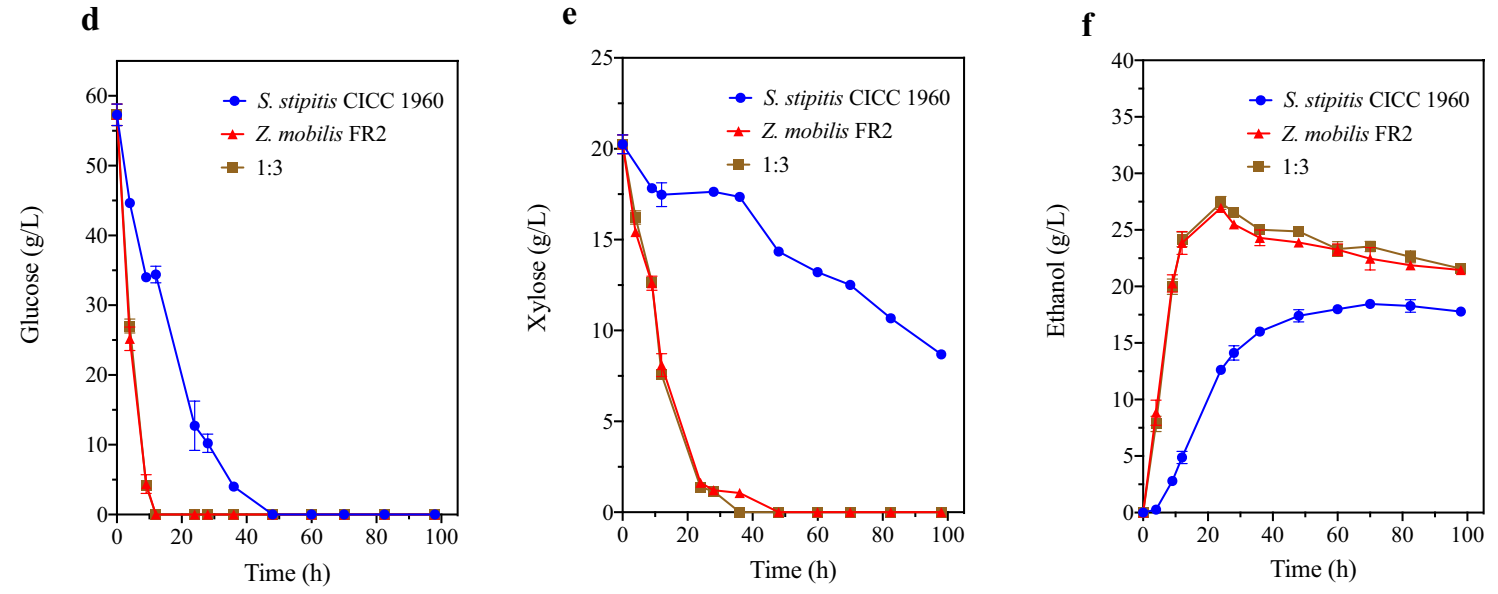

g

h

i
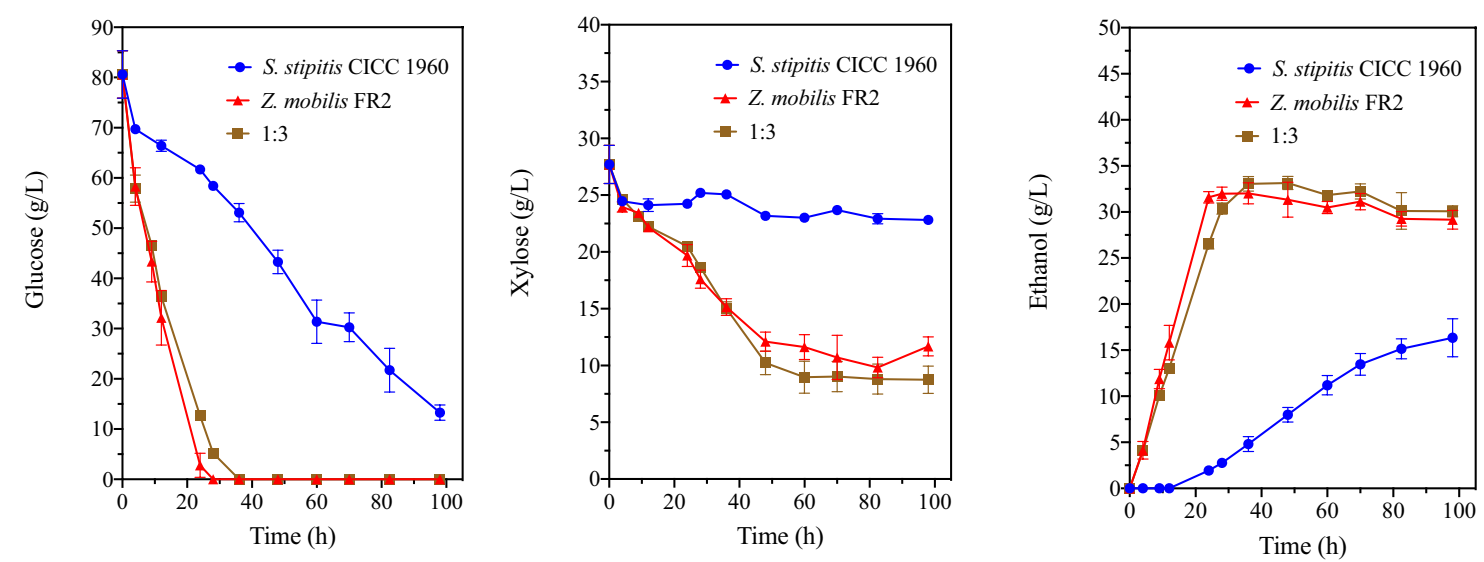

Fig. 4 Consortium fermentation profiles in variousconcentrations of corn stover hydrolysates. a, b, c Glucose, xylose and ethanol fermentation profiles in $60 \mathrm{~g} / \mathrm{L}$ of corn stover hydrolysate. $\mathbf{d}, \mathbf{e}, \mathbf{f}$ Glucose, xylose and ethanol fermentation profiles in $90 \mathrm{~g} / \mathrm{L}$ of corn stover hydrolysate. $\mathbf{g}, \mathbf{h}, \mathbf{i}$ Glucose, xylose and ethanol fermentation profiles in $120 \mathrm{~g} / \mathrm{L}$ of corn stover hydrolysate.The concentration of corn stover hydrolysates represents the total amount of glucose and xylose in the hydrolysates before autoclave sterilization. For consortium fermentation, the inoculation ratio between $S$. stipitis CICC1960 and Z. mobilis FR2 was 1:3. Data are mean \pm standard error from three replicates 
Table 2 Fermentation profiles in the corn stover hydrolysate

\begin{tabular}{|c|c|c|c|c|c|c|}
\hline \multirow{2}{*}{ 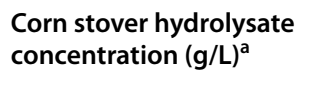 } & \multirow{2}{*}{$\begin{array}{l}\text { S. stipitis } \\
\text { CICC1960:Z. mobilis } \\
\text { FR2 }\end{array}$} & \multirow{2}{*}{$\begin{array}{l}\text { Glucose } \\
\text { consumed }(g / L)^{b}\end{array}$} & \multirow{2}{*}{$\begin{array}{l}\text { Xylose } \\
\text { consumed } \\
(\mathrm{g} / \mathrm{L})^{\mathrm{b}}\end{array}$} & \multicolumn{3}{|l|}{ Ethanol $^{b}$} \\
\hline & & & & Titer (g/L) & Yield $(g / g)$ & Productivity (g/L/h) \\
\hline \multirow[t]{3}{*}{60} & $1: 0$ & $38.27 \pm 0.53$ & $8.64 \pm 0.49$ & $13.40 \pm 0.75$ & $0.29 \pm 0.01$ & $0.73 \pm 0.04$ \\
\hline & $0: 1$ & $38.27 \pm 0.53$ & $13.50 \pm 0.00$ & $18.72 \pm 0.46$ & $0.36 \pm 0.01$ & $2.08 \pm 0.05$ \\
\hline & $1: 3$ & $38.27 \pm 0.53$ & $13.50 \pm 0.00$ & $19.58 \pm 0.32$ & $0.38 \pm 0.01$ & $2.18 \pm 0.04$ \\
\hline \multirow[t]{3}{*}{90} & $1: 0$ & $57.30 \pm 1.55$ & $7.74 \pm 0.25$ & $18.45 \pm 0.35$ & $0.28 \pm 0.01$ & $0.53 \pm 0.01$ \\
\hline & $0: 1$ & $57.30 \pm 1.55$ & $18.62 \pm 0.15$ & $26.96 \pm 0.24$ & $0.36 \pm 0.00$ & $1.99 \pm 0.08$ \\
\hline & $1: 3$ & $57.30 \pm 1.55$ & $18.87 \pm 0.04$ & $27.38 \pm 0.58$ & $0.36 \pm 0.01$ & $2.01 \pm 0.05$ \\
\hline \multirow[t]{3}{*}{120} & $1: 0$ & $67.35 \pm 1.52$ & $4.88 \pm 0.19$ & $16.35 \pm 2.06$ & $0.23 \pm 0.03$ & $0.19 \pm 0.02$ \\
\hline & $0: 1$ & $80.61 \pm 4.72$ & $12.56 \pm 0.74$ & $32.03 \pm 1.14$ & $0.34 \pm 0.01$ & $1.32 \pm 0.03$ \\
\hline & $1: 3$ & $80.61 \pm 4.72$ & $12.69 \pm 0.60$ & $33.05 \pm 0.79$ & $0.35 \pm 0.01$ & $1.11 \pm 0.02$ \\
\hline
\end{tabular}

Data are mean \pm standard error from three replicates

${ }^{a}$ The corn stover hydrolysate concentration refers to the total concentrations of glucose and xylose in the hydrolysate before autoclave sterilization

${ }^{\mathrm{b}}$ All data were calculated based on the real sugar concentrations

Exploring the interactions between $S$. stipitis and $Z$. mobilis under various cell densities, as well as the ethanol fermentation performance in corn stover hydrolysate by co-immobilized cells of the two species, are our future research goals. Indeed, a deep understanding of the interactions between $S$. stipitis and Z. mobilis and the mechanisms behind the protective role of co-immobilization on cells will pave the way to further enhance the consortium fermentation performance while lowering the inoculum size, and will help promoting the industrial progression of cellulosic ethanol production.

\section{Analysis of gene expression by qRT-PCR}

As for the outstanding fermentation ability of the inoculum ratio 1:3 between S. stiptis and Z. mobilis with "high density", genes of xylose and glucose transporters in two strains and carbon catabolite repressor (CCR) in S. stipitis were chosen to qRT-PCR analysis. Samples were taken at $3,9,21$ and $27 \mathrm{~h}$, respectively, and the gene expressions in the consortia were compared with that of corresponding mono-fermentation at the same time. As shown in Fig. 5, at the early stage of fermentation ( $3 \mathrm{~h}$ ), genes related to xylose and glucose transporters in $S$. stipitis (XUT4, XUT5, XUT7, SNF3, QUP2, RGT2, HGT1, HGT2) and Z. mobilis (ZMO 0366, ZMO 0293) had no significant differences between the consortium (1:3) and mono-fermentation. However, these genes in the consortium (1:3) were up-regulated to some different extent compared with that in mono-fermentation at $9 \mathrm{~h}$ and $21 \mathrm{~h}$. For example, XUT5 and XUT7 related xylose transporter of S. stipitis in the consortium (1:3) had a 155.1and 5.8-fold enhanced expression at $9 \mathrm{~h}$, respectively, compared to the mono-fermentation of S. stipitis, even 549.5-fold for XUT5 at $21 \mathrm{~h}$. Among glucose transporter related genes including SNF3, QUP2, RGT2 and HGT1 of $S$. stipitis in the consortium (1:3) were up-regulated about 17.1-, 68.9-, 7.9-, and 185.6-fold at 9 h, respectively, compared to $S$. stipitis mono-fermentation. At the same time, the gene ZMO0366 (glucose facilitated diffusion protein) and ZMO0293 (sugar porter family MFS transporter) came from $Z$. mobilis also had about 9.9-, 13.6-fold up-regulation at $9 \mathrm{~h}$ in the consortium (1:3), respectively. These results above were in consistent with the results of fermentation ability, which could explain why the utilizations of xylose and glucose in the consortium (1:3) were better than that of S. stipitis mono-fermentation and Z. mobilis mono-fermentation (Fig. 1). The higher the expression of xylose or glucose transporter, the more xylose or glucose could be transported for utilization. In addition, the gene $Z M O 0366$ and $Z M O$ 0293 also had about 7.9-, 14.8-fold up-regulation at $9 \mathrm{~h}$ in the consortium of $3: 1$, respectively, which were comparable to the consortium of 1:3. The finding showed that the up-regulation of genes related xylose and glucose transporters came from $S$. stipitis played an important role in the consortium of 1:3. It has been reported that Mig2 was identified as a repressor that collaborates with Mig1 to cause glucose-induced repression of $S U C 2$ gene [37]. Mig2 could be also involved in the cross talk between the nucleus and the mitochondria through Ups1 to regulate mitochondrial morphology in a glucose dependent manner [37, 38]. Interesting, the expression of Mig1 gene came from S. stipitis was down-regulated at $9 \mathrm{~h}$ and $21 \mathrm{~h}$ in the consortium compared to S. stipitis mono-fermentation, while Mig2 were up-regulated. Therefore, it could be speculated that the down-regulation of Mig1 could contribute to reducing CCR, and Mig2 might play a more important role compared to Mig1 in the consortium. 

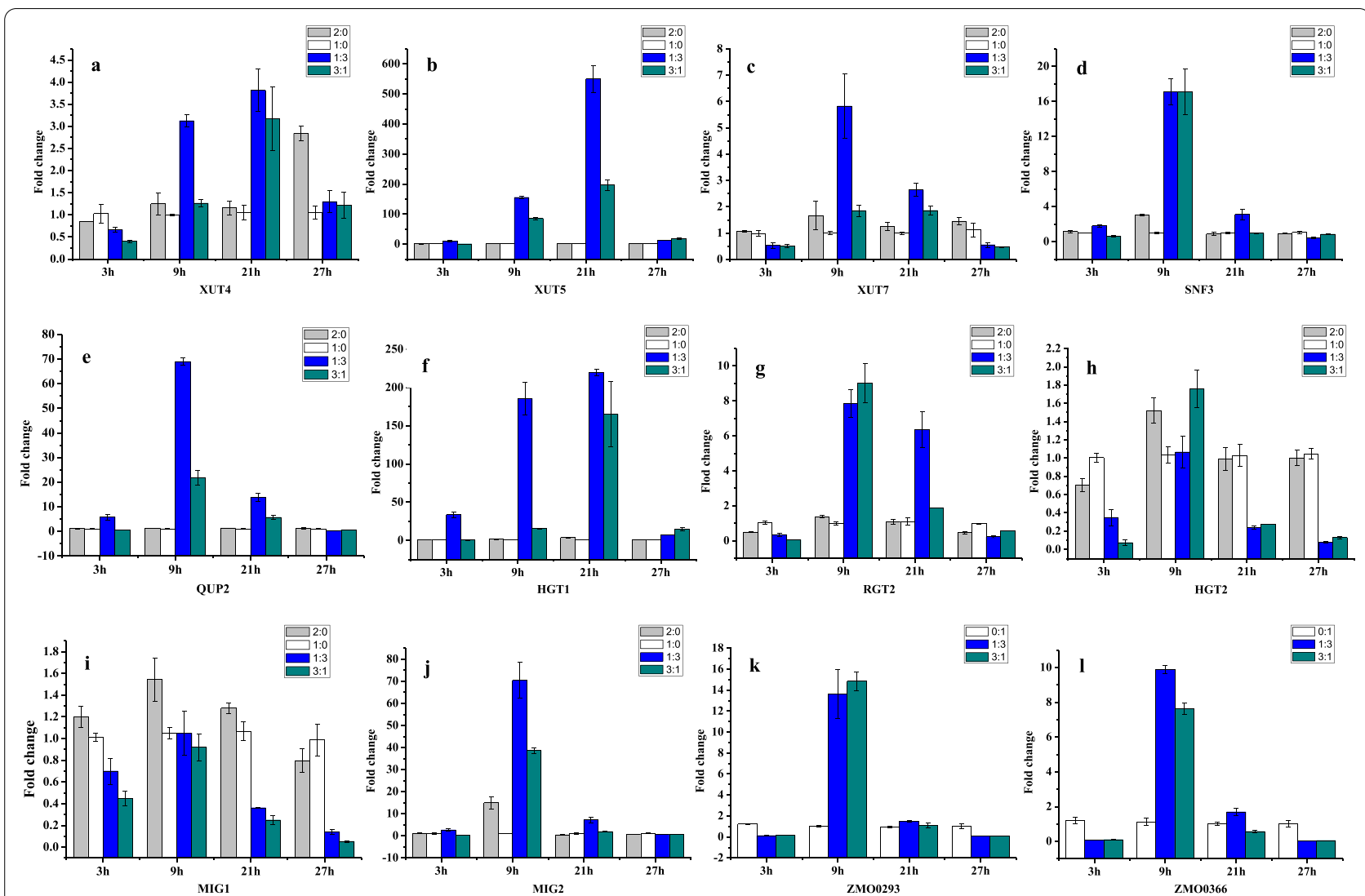

Fig. 5 Fold changes in xylose/glucose transporters and CCR gene expression levels of consortia and control mono-fermentation. $\mathbf{a}$, $\mathbf{b}$, $\mathbf{c}$ Xylose transporter in S. stipitis; $\mathbf{d}, \mathbf{e}, \mathbf{f}, \mathbf{g}, \mathbf{h}$ Glucose transporter in S. stipitis; i, j Carbon catabolite repressor (CCR) in S. stipitis; $\mathbf{k}$, I Glucose/xylose transporter in Z. mobilis.

From Fig. 5, we also found that the increase of initial inoculation of S. stipitis in mono-fermentation didn't cause changes in the expression levels of xylose and glucose transporters and CCR genes, which was consistent with the fermentation results, that is, the increase of $S$. stipitis initial inoculation didn't improve the fermentation performance of mono-fermentation. Gao et al. have reported that the initial ratio can influence the structure and, more importantly, the function and the bacterial interaction of a community [39]. Our results suggested that there might be an interaction between S. stipitis and $Z$. mobilis and the initial ratio of $1: 3$ is able to regulate the expression of genes of xylose and glucose transporters in two strains to better utilize glucose and xylose simultaneously.

\section{Conclusions}

This study focused on evaluating a fermentation method to efficiently transform glucose and xylose to ethanol via artificial consortia composed of suspended S. stipitis and suspended Z. mobilis. By fermentation process optimization and genetic engineering, the consortium built here exhibited enhanced xylose assimilation ability and ethanol production performance in both 80G40XRM and corn stover hydrolysates, and did not experience evident CCR phenomenon. Hence, this study proved that S. stipitis and Z. mobilis could be co-cultured together in suspension in cellulosic ethanol production and provided a novel strategy for further application.

\section{Materials and methods}

\section{Strains, plasmids and primers}

S. stipitis CICC1960 was purchased from the China Center of Industrial Culture Collection. Z. mobilis $8 \mathrm{~b}$ was kindly given by Shihui Yang, Hubei University, and was used as the starting strain for further strains constructions. Plasmid Pmini was kindly given by Nan Peng, Huazhong Agricultural University. All primers were synthesized by Tsingke Biotechnology Co., Ltd. (Chengdu, China) and purified via polyacrylamide gel electrophoresis.

All strains, plasmids and sgRNAs are listed in Additional file 1: Table S3. Primers are listed in Additional file 1: Table S4. 


\section{Genetic engineering and strain development}

The CRISPR-Cas system was used to engineer Z. mobilis FR1 and Z. mobilis FR2 in this study. Specifically, the plasmids Pmini- $\mathrm{P}_{p d c}-t a l B-t k t A$ and Pmini- $\mathrm{P}_{p d c}-x y l A-x y l B$ were constructed using Gibson Assembly ${ }^{\circledR}$ Protocol (New England BioLabs, Ipswich, US) and were transformed into E. coli trans110 (TransGen Biotech, Beijing, China). After verification of the plasmid sequences by sequencing, the two plasmids were transformed into $Z$. mobilis $8 \mathrm{~b}$ sequentially to construct $Z$. mobilis FR1 (ZMO0256:: $\mathrm{P}_{p d c^{-}}$ talB-tktA) and Z. mobilis FR2 (ZMO0256:: $\mathrm{P}_{p d c}$-talB-tktA; ZMO0689:: $\left.\mathrm{P}_{p d c}-x y l A-x y l B\right)$. ZMO0256up500, pdc promoter, talB, tktA, ZMO0256down500, ZMO0689up540, $x y l A, x y l B$, and ZMO0689down500 were all amplified from $Z$. mobilis $8 \mathrm{~b}$, using the corresponding primers listed in Additional file 1: Table S4. Only the engineered strains confirmed by both gel electrophoresis and gene sequencing were used in the experiments.

\section{Preparation of the corn stover hydrolysates Alkaline pretreatment [40]}

Corn stover was collected from Jianyang, Sichuan, China. After air-drying, milling and passing through a sieve with an aperture size of $380 \mu \mathrm{m}$, the corn stover was mixed with $1.34 \%(\mathrm{w} / \mathrm{v}) \mathrm{NaOH}$ solution (The solid loading was $10 \%(\mathrm{w} / \mathrm{v}))$, loaded into reaction kettles, and transferred into a drying oven sequentially. The treatment parameters were $140{ }^{\circ} \mathrm{C}$ and $6 \mathrm{~h}$.

The pretreated corn stover was washed intensively with water or diluted $\mathrm{HNO}_{3}$ until the $\mathrm{pH}$ of the washing water turned neutral. The washed corn stover was oven dried and stored in sealed bags at room temperature.

\section{Enzymatic hydrolysis}

Pretreated corn stover $(10 \mathrm{~g})$ was mixed with $100 \mathrm{~mL}$ citric acid buffer $(8.823 \mathrm{~g} / \mathrm{L}$ tri-sodium citrate dihydrate, $3.843 \mathrm{~g} / \mathrm{L}$ citric acid, $\mathrm{pH} 4.8$ ) and $5 \mathrm{~mL}$ cellulase (SigmaAldrich, Saint Louis, US). Afterwards, the mixture was placed in an incubator at $50{ }^{\circ} \mathrm{C}$ and $150 \mathrm{rpm}$ for $72 \mathrm{~h}$. When the enzymatic hydrolysis was finished, the hydrolysate was centrifuged twice at $3000 \mathrm{~g}$ for $25 \mathrm{~min}$ each time. The hydrolysate was then centrifuged again at $10,000 \mathrm{~g}$ for $5 \mathrm{~min}$ for the further removal of the remaining solids. Sugars in the lignocellulosic hydrolysate were concentrated using a rotary evaporator to attain $60 \mathrm{~g} / \mathrm{L}$, $90 \mathrm{~g} / \mathrm{L}$, and $120 \mathrm{~g} / \mathrm{L}$ hydrolysates with regard to the concentrations of total glucose and xylose. Subsequently, $10 \mathrm{~g} / \mathrm{L}$ yeast extract, $2 \mathrm{~g} / \mathrm{L} \mathrm{KH}_{2} \mathrm{PO}_{4}, 1 \mathrm{~g} / \mathrm{L}\left(\mathrm{NH}_{4}\right)_{2} \mathrm{SO}_{4}$, and $2 \mathrm{~g} / \mathrm{L} \mathrm{MgSO}_{4} \cdot 7 \mathrm{H}_{2} \mathrm{O}$ were added to the hydrolysates before adjusting the $\mathrm{pH}$ of the hydrolysates to 5.6 by $5 \mathrm{M}$ $\mathrm{NaOH}$.

\section{Growth and fermentation conditions}

\section{Preparation of the seed cultures of S. Stipitis and Z. mobilis}

Scheffersomyces stipitis was streaked in a YPD plate (20 g/L glucose, $10 \mathrm{~g} / \mathrm{L}$ yeast extract, $20 \mathrm{~g} / \mathrm{L}$ peptone, and $15 \mathrm{~g} / \mathrm{L}$ agar) and cultured at $30{ }^{\circ} \mathrm{C}$ for approximately 1 day. A single colony was transferred from the YPD plate into $5 \mathrm{~mL}$ of YP120X medium $(120 \mathrm{~g} / \mathrm{L}$ xylose, $10 \mathrm{~g} / \mathrm{L}$ yeast extract, and $20 \mathrm{~g} / \mathrm{L}$ peptone) and cultivated at $30{ }^{\circ} \mathrm{C}$ and $150 \mathrm{rpm}$ for $19-36 \mathrm{~h}$. Afterwards, the entire pre-seed culture was inoculated into a $100 \mathrm{~mL}$ of fresh YP120X medium and cultivated at $30{ }^{\circ} \mathrm{C}$ and $150 \mathrm{rpm}$ for $22 \mathrm{~h}$. At this point, the $\mathrm{OD}_{600}$ value of the seed culture was approximately 1.8 .

Similarly, Z. mobilis was streaked in a RM plate $(20 \mathrm{~g} / \mathrm{L}$ glucose, $10 \mathrm{~g} / \mathrm{L}$ yeast extract, $2 \mathrm{~g} / \mathrm{L} \mathrm{KH}_{2} \mathrm{PO}_{4}, 1 \mathrm{~g} / \mathrm{L}$ $\left(\mathrm{NH}_{4}\right)_{2} \mathrm{SO}_{4}, 2 \mathrm{~g} / \mathrm{L} \mathrm{MgSO}_{4} \cdot 7 \mathrm{H}_{2} \mathrm{O}$, and $15 \mathrm{~g} / \mathrm{L}$ agar $)$ and cultivated at $30{ }^{\circ} \mathrm{C}$ for 2 days. A single colony was transferred from the RM plate into $5 \mathrm{~mL}$ of $80 \mathrm{G} 40 X R M(80 \mathrm{~g} / \mathrm{L}$ glucose, $40 \mathrm{~g} / \mathrm{L}$ xylose, $10 \mathrm{~g} / \mathrm{L}$ yeast extract, $2 \mathrm{~g} / \mathrm{L} \mathrm{KH}_{2} \mathrm{PO}_{4}$, $1 \mathrm{~g} / \mathrm{L}\left(\mathrm{NH}_{4}\right)_{2} \mathrm{SO}_{4}$, and $\left.2 \mathrm{~g} / \mathrm{L} \mathrm{MgSO}_{4} \cdot 7 \mathrm{H}_{2} \mathrm{O}\right)$ and cultivated statically at $30{ }^{\circ} \mathrm{C}$ for $19-36 \mathrm{~h}$. The entire culture was then inoculated into $100 \mathrm{~mL}$ of the fresh 80G40XRM and cultivated statically at $30{ }^{\circ} \mathrm{C}$ for $22 \mathrm{~h}$. The $\mathrm{OD}_{600}$ value of the seed culture was approximately 1.8 at this point.

\section{Fermentation conditions}

For the "high density" inoculation fermentation, the seed cultures of S. stipitis and $Z$. mobilis were centrifuged at $4{ }^{\circ} \mathrm{C}$ with $4000 \mathrm{rpm}$ for $5 \mathrm{~min}$, washed once with sterile $\mathrm{dd}_{2} \mathrm{O}$, and suspended with $1 / 25$ (v/v) new fermentation medium, respectively (for 80G40XRM fermentation, 80G40XRM was used to suspend cells, while sterile $\mathrm{ddH}_{2} \mathrm{O}$ was used for corn stover hydrolysates fermentation). The concentrated cells were then inoculated into the corresponding fermentation medium with different ratios of $S$. stipitis and $Z$. mobilis. The total inoculum size was $100 \%(\mathrm{v} / \mathrm{v}$, the ratio of seed culture volume/fermentation culture volume). For the "low amount" inoculation fermentation, after centrifuging and washing, the seed cultures of S. stipitis and Z. mobilis were added proper 80 G40XRM to suspend cells to make $\mathrm{OD}_{600}$ value about 1.0.The total fermentation volume was $50 \mathrm{~mL}$ for 80G40XRM fermentation and $10 \mathrm{~mL}$ for corn stover hydrolysates fermentation. The fermentation conditions were $30{ }^{\circ} \mathrm{C}$ and $150 \mathrm{rpm}$, unless there was further indication in the portion for exploring the effect of oxygen on $Z$. mobilis fermentation (as seen in Section "Effect of oxygen on Z. mobilis FR2 fermentation").

Four replicates were performed for the 80G40XRM fermentation, while three replicates were performed for the corn stover hydrolysates fermentation. 


\section{Analytical methods}

Determination of glucose, xylose and ethanol concentrations during fermentation

The glucose, xylose, and ethanol titers in the fermentation samples were analyzed by an Agilent 1200 Series HPLC system (Agilent Technologies, Santa Clara, US) equipped with a Bio-Rad HPX-87H column (Bio-Rad Laboratories, Richmond, US). The mobile phase was $5 \mathrm{mM} \mathrm{H}_{2} \mathrm{SO}_{4}$. The operating parameters were $20 \mu \mathrm{L}$ injection volume, $0.6 \mathrm{~mL} / \mathrm{min}$ rate, and $35^{\circ} \mathrm{C}$. The ethanol productivity and yield were calculated using the following formulas.

(1) Ethanol productivity = Ethanol titer/fermentation time.

(2) Ethanol yield = Ethanol titer/glucose and xylose consumed.

The theoretical ethanol yield is $0.51 \mathrm{~g} / \mathrm{g}$ sugars consumed.

\section{Quantitative real-time reverse transcription $P C R$}

Total cellular RNA was extracted from cells grown for $3 \mathrm{~h}, 9 \mathrm{~h}, 21 \mathrm{~h}$ and $24 \mathrm{~h}$ using Trizol reagent (Invitrogen). Reverse transcription step was carried out using Goldenstar RT6 cDNA Synthesis Kit Ver 2 (TsingKe, Chengdu, China) with random primer mix following the manufacturer's manual. Quantitative real-time reverse transcription PCR was performed in the Bio-Rad iQ5 real-time PCR detection system with SuperReal PreMix (SYBR Green) (TIANGEN, Beijing, China). All optimized primers are shown in Table S4 and were designed using primer software to amplify approximately $100 \mathrm{bp}$ from the $3^{\prime}$ end of the target genes. PCR conditions were $1 \mathrm{~min}$ at $95^{\circ} \mathrm{C}$, followed by 40 cycles of heating at $95^{\circ} \mathrm{C}$ for $15 \mathrm{~s}$ and $60{ }^{\circ} \mathrm{C}$ for $15 \mathrm{~s}$, and $72{ }^{\circ} \mathrm{C}$ for $30 \mathrm{~s}$, and final extension at $72{ }^{\circ} \mathrm{C}$ for $5 \mathrm{~min}$. PCR amplification was detected by SYBR Green. The ratios of the cycle threshold $(\mathrm{Ct})$ values were determined from the Bio-Rad iQ5 Optical System Software provided. To analyze the gene expression level, the $\Delta \Delta \mathrm{Ct}$ method was chosen and standard curves of each primer were plotted to ensure similar amplification efficiency compared with the reference gene. The $r r s A$ gene, encoding the 16S RNA, and $t d h 2$ gene served as an endogenous control to normalize for differences in total RNA for Z. mobilis 8b, and S. stipitis, respectively.

\section{Statistical analysis}

Data are presented as mean \pm standard error. All figures were prepared using Prism 8 (GraphPad Software, LLC).

Significant differences were statistically analyzed using IBM $^{\circledR}$ SPSS $^{\circledR}$ Statistics (Version 22, US). If $\mathrm{P}>0.05$ in the homogeneity of variance tests, a one-way ANOVA followed by $T$ test was used. Otherwise, a nonparametric test (Kruskal-Wallis $\mathrm{H}$ ) was used.

\section{Supplementary Information}

The online version contains supplementary material available at https://doi. org/10.1186/s13068-021-02069-8.

Additional file 1: Figure S1. Fermentation profiles of consortia consisting of S. stipitis CICC1960 and Z. mobilis 8b in 80G40XRM with "low amount" inoculums of fermentations. a Glucose assimilation profiles. b Xylose assimilation profiles. c Ethanol production profiles. Data are mean \pm standard error from four replicates. Figure S2. Pentose metabolism and Entner-Doudoroff pathways in engineered Z. mobilis (1). Table S1. Fermentation profiles of consortia consisting of S. stipitis CICC1960 and Z. mobilis $8 \mathrm{~b}$ in 80G40XRM. Table S2. Fermentation profiles of Z. mobilis 8b, Z. mobilis FR1, and Z. mobilis FR2 in 80G40XRM. Table S3. Strains, plasmids, and sgRNAs used in this study. Table S4. Primers used in this study.

Acknowledgements

Not applicable.

\section{Authors' contributions}

Experimental design was carried by LS, BW, PL, QZ, MH, and FT. Data acquisition was performed by LS. Data was analyzed by LS, JY. Manuscript was written by $L S$ and ZZ, and was revised by PL, CS, SS, QZ, SY, NP and FT. All authors read and approved the final manuscript.

\section{Funding}

This work was supported by Sichuan Science and Technology Program (No. 2020YFH0021 and 2020YFN0015), Central Public-Interest Scientific Institution Basal Research Fund (No. 1610012017004_05102), and Agricultural Science and Technology Innovation Project of Chinese Academy of Agricultural Sciences (CAAS-ASTIP-2016-BIOMA).

Availability of data and materials

Not applicable.

\section{Declarations}

Ethics approval and consent to participate

Not applicable.

\section{Consent for publication}

Not applicable.

\section{Competing interests}

The authors declare that they have no competing interests.

\section{Author details}

${ }^{1}$ Key Laboratory of Development and Application of Rural Renewable Energy, Ministry of Agriculture and Rural Affairs, Biogas Institute of Ministry of Agriculture and Rural Affairs, Chengdu 610041, China. ${ }^{2}$ Graduate School of Chinese Academy of Agricultural Sciences, Beijing 100081, China. ${ }^{3}$ Hubei Collaborative Innovation Center for Green Transformation of Bio-Resources, Environmental Microbial Technology Center of Hubei Province, Hubei Key Laboratory of Industrial Biotechnology, College of Life Sciences, Hubei University, Wuhan 430062, China. ${ }^{4}$ State Key Laboratory of Agricultural Microbiology, College of Life Science and Technology, Huazhong Agricultural University, Wuhan 430070, China. ${ }^{5}$ Chengdu National Agricultural Science and Technology Center, Chengdu 610221, China.

Received: 18 July 2021 Accepted: 10 November 2021 Published online: 25 November 2021

References

1. Jehadin F, Rabeya T, Asad MA, Ayodele OO, Adekunle AE, Islam MS. Efficient conversion of cornstalk to bioethanol using dilute $\mathrm{H}_{2} \mathrm{SO}_{4}$ pretreatment. Int J Energy Environ Eng. 2021;12:203-11. 
2. Zhang M, Eddy C, Deanda K, Finkelstein M, Picataggio S. Metabolic engineering of a pentose metabolism pathway in ethanologenic Zymomonas mobilis. Science. 1995;267:240-3.

3. Sun JD, Tang C, Zhou J, Wei P, Wang YJ, An W, Yan ZY, Yong XY. Production of poly- $\gamma$-glutamic acid ( $\gamma$-PGA) from xylose-glucose mixtures by Bacillus amyloliquefaciens C1. 3 Biotech. 2021;11:100.

4. Lopez PC, Udugama IA, Thomsen ST, Bayer C, Junicke H, Gernaey KV. Promoting the co-utilisation of glucose and xylose in lignocellulosic ethanol fermentations using a data-driven feed-back controller. Biotechnol Biofuels. 2020;13:190.

5. Barthe M, Tchouanti J, Gomes PH, Bideaux C, Lestrade D, Graham C, Steyer J-P, Meleard S, Harmand J, Gorret N, et al. Availability of the molecular switch XyIR controls phenotypic heterogeneity and lag duration during Escherichia coli adaptation from glucose to xylose. mBio. 2020;11:e02938-02920.

6. Farwick A, Bruder S, Schadeweg V, Oreb M, Boles E. Engineering of yeast hexose transporters to transport D-xylose without inhibition by D-glucose. Proc Natl Acad Sci USA. 2014;111:5159-64.

7. Li H, Schmitz O, Alper HS. Enabling glucose/xylose co-transport in yeast through the directed evolution of a sugar transporter. Appl Microbiol Biotechnol. 2016;100:10215-23.

8. Wang M, Yu C, Zhao H. Directed evolution of xylose specific transporters to facilitate glucose-xylose co-utilization. Biotechnol Bioeng. 2016:113:484-91.

9. Fox KJ, Prather KL. Carbon catabolite repression relaxation in Escherichia coli: global and sugar-specific methods for glucose and secondary sugar co-utilization. Curr Opin Chem Eng. 2020;30:9-16.

10. Sievert C, Nieves LM, Panyon LA, Loeffler T, Morris C, Cartwright RA, Wang $X$. Experimental evolution reveals an effective avenue to release catabolite repression via mutations in XyIR. Proc Natl Acad Sci USA. 2017;114:7349-54.

11. Zhao C, Sinumvayo JP, Zhanga Y, Li Y. Design and development of a "Y-shaped" microbial consortium capable of simultaneously utilizing biomass sugars for efficient production of butanol. Metab Eng. 2019:55:111-9.

12. Karagöz P, Özkan M. Ethanol production from wheat straw by Saccharomyces cerevisiae and Scheffersomyces stipitis co-culture in batch and continuous system. Bioresour Technol. 2014;158:286-93.

13. Xia J, Yang Y, Liu C-G, Yang S, Bai F-W. Engineering Zymomonas mobilis for robust cellulosic ethanol production. Trends Biotechnol. 2019;37:960-72.

14. Yang S, Vera JM, Grass J, Savvakis G, Moskvin OV, Yang Y, Mcllwain SJ, Lyu Y, Zinonos I, Hebert AS, et al. Complete genome sequence and the expression pattern of plasmids of the model ethanologen Zymomonas mobilis ZM4 and its xylose-utilizing derivatives $8 \mathrm{~b}$ and 2032. Biotechnol Biofuels. 2018;11:125.

15. Chaudhary G, Ghosh S. Two-reactor, continuous culture fermentation for fuel ethanol production from lignocellulosic acid hydrolysate using Zymomonas mobilis and Scheffersomyces stipitis. RSC Adv. 2014;4:36412-8.

16. Singh LK, Majumder CB, Ghosh S. Development of sequential-co-culture system (Pichia stipitis and Zymomonas mobilis) for bioethanol production from Kans grass biomass. Biochem Eng J. 2014;82:150-7.

17. Wirawan F, Cheng CL, Lo YC, Chen CY, Chang JS, Leu SY, Lee DJ. Continuous cellulosic bioethanol co-fermentation by immobilized Zymomonas mobilis and suspended Pichia stipitis in a two-stage process. Appl Energy. 2020;266: 114871

18. Fu N, Peiris P, Markham J, Bavor J. A novel co-culture process with Zymomonas mobilis and Pichia stipitis for efficient ethanol production on glucose/xylose mixtures. Enzyme Microb Technol. 2009;45:210-7.

19. Nguyen DTT, Praveen P, Loh K-C. Co-culture of Zymomonas mobilis and Scheffersomyces stipitis immobilized in polymeric membranes for fermentation of glucose and xylose to ethanol. Biochem Eng J. 2019;145:145-52.

20. Jiang D, Ge X, Zhang T, Liu H, Zhang Q. Photo-fermentative hydrogen production from enzymatic hydrolysate of corn stalk pith with a photosynthetic consortium. Int J Hydrogen Energy. 2016;41:16778-85.

21. Lau MW, Dale BE. Cellulosic ethanol production from AFEX-treated corn stover using Saccharomyces cerevisiae 424A(LNH-ST). Proc Natl Acad Sci USA. 2009;106:1368-73.

22. Slininger PJ, Thompson SR, Weber S, Liu ZL, Moon J. Repression of xylose-specific enzymes by ethanol in Scheffersomyces (Pichia) stipitis and utility of repitching xylose-grown populations to eliminate diauxic lag. Biotechnol Bioeng. 2011;108:1801-15.
23. Mohagheghi A, Dowe N, Schell D, Chou Y-C, Eddy C, Zhang M. Performance of a newly developed integrant of Zymomonas mobilis for ethanol production on corn stover hydrolysate. Biotechnol Lett. 2004;26:321-5.

24. Agrawal M, Mao Z, Chen RR. Adaptation yields a highly efficient xylose-fermenting Zymomonas mobilis strain. Biotechnol Bioeng. 2011;108:777-85.

25. Viitanen PV, Chou YC, Mccutchen CM, Zhang M. Xylitol synthesis mutant of xylose-utilizing zymomonas for ethanol production. vol. US007741119B2. United states; 2010.

26. Sarkar P, Mukherjee M, Goswami G, Das D. Adaptive laboratory evolution induced novel mutations in Zymomonas mobilis ATCC ZW658: a potential platform for co-utilization of glucose and xylose. J Ind Microbiol Biotechnol. 2020;47:329-41.

27. Gao Q, Zhang M, Mcmillan JD, Kompala DS. Characterization of heterologous and native enzyme activity profiles in metabolically engineered Zymomonas mobilis strains during batch fermentation of glucose and xylose mixtures. Appl Biochem Biotechnol. 2002;98-100:341-55.

28. Jeon YJ, Svenson CJ, Rogers PL. Over-expression of xylulokinase in a xylose-metabolising recombinant strain of Zymomonas mobilis. FEMS Microbiol Lett. 2005;244:85-92.

29. Tanaka H, Ishikawa H, Osuga K, Takagi Y. Fermentative ability of Zymomonas mobilis under various oxygen supply conditions in batch culture. J Ferment Bioeng. 1990;69:234-9.

30. Ishikawa H, Nobayashi H, Tanaka H. Mechanism of fermentation performance of Zymomonas mobilis under oxygen supply in batch culture. J Ferment Bioeng. 1990;70:34-40.

31. Hayashi T, Furuta Y, Furukawa K. Respiration-deficient mutants of Zymomonas mobilis show improved growth and ethanol fermentation under aerobic and high temperature conditions. J Biosci Bioeng. 2011;111:414-9.

32. Hayashi T, Kato T, Furukawa K. Respiratory chain analysis of Zymomonas mobilis mutants producing high levels of ethanol. Appl Environ Microbiol. 2012;78:5622-9.

33. Kalnenieks U, Galinina N, Strazdina I, Kravale Z, Pickford JL, Rutkis R, Poole RK. NADH dehydrogenase deficiency results in low respiration rate and improved aerobic growth of Zymomonas mobilis. Microbiology. 2008;154:989-94.

34. Franden MA, Pilath HM, Mohagheghi A, Pienkos PT, Zhang M. Inhibition of growth of Zymomonas mobilis by model compounds found in lignocellulosic hydrolysates. Biotechnol Biofuels. 2013;6:99.

35. Amutha R, Gunasekaran P. Production of ethanol from liquefied cassava starch using co-immobilized cells of Zymomonas mobilis and Saccharomyces diastaticus. J Biosci Bioeng. 2001;92:560-4.

36. Kong W, Meldgin DR, Collins JJ, Lu T. Designing microbial consortia with defined social interactions. Nat Chem Biol. 2018;14:821-9.

37. Lutfiyya LL, lyer VR, DeRisi J, DeVit MJ, Brown PO, Johnston M. Characterization of three related glucose repressors and genes they regulate in Saccharomyces cerevisiae. Genetics. 1998;150:1377-91.

38. Fernández-Cid A, Riera A, Herrero P, Moreno F. Glucose levels regulate the nucleo-mitochondrial distribution of Mig2. Mitochondrion. 2012;12:370-80.

39. Gao $\mathrm{C}-\mathrm{H}, \mathrm{Cao} \mathrm{H}, \mathrm{Cai} \mathrm{P}$, Sørensen SJ. The initial inoculation ratio regulates bacterial coculture interactions and metabolic capacity. ISME J. 2021;15:29-40

40. You Y, Liu S, Wu B, Wang Y-W, Zhu Q-L, Qin H, Tan F-R, Ruan Z-Y, Ma K-D, Dai L-C, et al. Bio-ethanol production by Zymomonas mobilis using pretreated dairy manure as a carbon and nitrogen source. RSC Adv. 2017;7:3768-79.

41. Gutierrez-Rivera B, Waliszewski-Kubiak K, Carvajal-Zarrabal O, AguilarUscanga MG. Conversion efficiency of glucose/xylose mixtures for ethanol production using Saccharomyces cerevisiae ITV01 and Pichia stipitis NRRL Y-7124. J Chem Technol Biotechnol. 2012;87:263-70.

42. Ashoor S, Comitini F, Ciani M. Cell-recycle batch process of Scheffersomyces stipitis and Saccharomyces cerevisiae co-culture for second generation bioethanol production. Biotechnol Lett. 2015;37:2213-8.

\section{Publisher's Note}

Springer Nature remains neutral with regard to jurisdictional claims in published maps and institutional affiliations. 